\title{
Tools for Measurement the Efficiency -Some Models and Its Applications
}

\author{
Iulian Lita \\ Bucharest University of Economic Studies \\ Romania
}

\begin{abstract}
Running the business as efficiently as possible - using human, natural and financial resources - has become the central objective for the development of any society. The efficiency of a firm can really be expressed by comparing the observed values of the input used by the firm and its output values with optimal input and / or output. In the literature, there are two approaches to determine the production boundary (parametric and nonparametric), both using information on the inputs used and the outputs produced by a producer group. This paper presents a non-parametric techniques named Data Envelopment Analysis (DEA) and its applications.
\end{abstract}

Keywords: data envelopment analysis, efficiency, mathematical programming

\section{Introduction}

Thus, the analysis and measurement of efficiency has become a complex task, especially due to conceptual challenges, multiple goals and an important concern for error measurement. In order to analyze this complexity, a number of specialized researches have been carried out in terms of organizational efficiency analysis. Starting from Farrell's core studies (1957), statisticians, econometrics and scientists have developed intricately analytical tools to measure the efficiency of organizations and systems production. Regarding the production process, an essential feature of it is effective. We distinguish at this level two types of efficiency: economic efficiency and production efficiency. Efficiency can also be analyzed either at industry or sector level, or across the national economy as a whole. The efficiency of a company is composed of two elements, combining them to determine total economic efficiency (Farrell, 1957).

We distinguish this way:

- allocation efficiency - describes the ability of a company (decision makers) to use inputs to an optimal extent using production technology and prices.

- technical efficiency - refers to the ability of a company (decision makers) to achieve the maximum output using a set of inputs;

A production process involves the existence of three components:

- inputs / resources: will either be consumed or transformed into a process;

- activities: operations through which inputs are transformed into outputs;

- outputs: the result of a production process. A production process combines two other processes, namely the labor process and the technological process. The technology process is a set of technological operations that aim to produce a product or components of this product. The human process involves the involvement of the human factor, which will act using the means of work.

\section{Methodology}

Charnes, Cooper, Rhodes (1978) used the optimization method of mathematical programming to generalize the Farrel (1957) single input / single output technique in the multi-input / multi-output case; so, data envelopment analysis is a linear programming methodology. The main feature of Charnes, Cooper, Rhodes's model (CCR model) is the multi-input / multi-output situation for each DMU decision unit at a single virtual output and a single virtual input report. This report provides a measure of efficiency for a given decision unit, which is a multiplier function. The objective is to find the largest sum of weighted outputs of the decision unit k, $D M U_{k}$ for $k=\overline{1, n}$, while maintaining the sum of inputs weighted at the value of the unit, forcing the relationship between the weighted output and the weighted input for any decision unit to be smaller than one. 
The CCR model is also known as the CRS and identifies inefficient units regardless of the size of the scale. In RCC models, there is both technical inefficiency and inefficiency in scale. Banker, Charnes and Cooper (1984) take into account the effect of scale yields within the decision-making group and at the same time identify its technical efficiency. To do this, the Banker, Charnes, Cooper (BCC model) introduces another convexity constraint to data coverage requirements. This model requires that the point of reference of the production function for each decision unit k, $D M U_{k}$ for $k=\overline{1, n}$, be a convex combination of the observed DMUs. The BCC model, known as Variable Return Model (VRS), provides the technical efficiency of investigated DMUs without any scale effect. Let's start with the relatively simple formulation of fractional programming of a DEA model, assuming there are $\mathrm{n}$ decision units $D M U_{k}$, for $k=\overline{1, n}$, to be evaluated. Each decision unit $\mathrm{k}, D M U_{k}$, for $k=\overline{1, n}$, consumes $\mathrm{m}$ inputs and produces different $p$ outputs, ie $D M U_{k}$ consumes input quantities to produce output quantities. It is assumed that these inputs and outputs are non-negative and each decision unit $\mathrm{k}, D M U_{k}$, for $k=\overline{1, n}$ has at least one positive input and output value. The efficiency of a decision unit $\mathrm{k}, D M U_{k}$, for $k=\overline{1, n}$, can then be written as follows:

$$
\Phi_{k}(\gamma, \lambda)=\frac{\sum_{j=1}^{p} \lambda_{j} y_{j k}}{\sum_{i=1}^{m} \gamma_{i} r_{i k}}, \text { pentru } k=\overline{1, n}
$$

In this formula $\gamma_{i}$ and $\lambda_{j}$ represent the coefficients (attributed weights) of the units reported for the input and output vectors for $i=\overline{1, m}$ and $j=\overline{1, p}$. The objective function of the decision unit $\mathrm{k}, D M U_{k}$, for $k=\overline{1, n}$, is given by the ratio between the weighted total output, divided by the weighted total input value, ie:

$\max _{\gamma_{i}, \lambda_{j}, \theta} \Phi_{k^{*}}(\gamma, \lambda)=\frac{\sum_{j=1}^{p} \lambda_{j} y_{j k^{*}}}{\sum_{i=1}^{m} \gamma_{i} r_{i k^{*}}}$

$\frac{\sum_{j=1}^{p} \lambda_{j} y_{j k}}{\sum_{i=1}^{m} \gamma_{i} r_{i k}} \leq 1$, for $k=\overline{1, n}$

$r_{i k} \geq 0$, for $i=\overline{1, m}$ și $k=\overline{1, n}$

$y_{j k} \geq 0$, for $j=\overline{1, p}$ şi $k=\overline{1, n}$

$\gamma_{i} \geq 0$, for $i=\overline{1, m}$

$\lambda_{j} \geq 0$, for $j=\overline{1, p}$

where: $r_{i k}$ and $y_{j k}$ - represent the problem variables for the decision unit k, $D M U_{k}$ for both inputs and outputs (the output and input values observed); $k^{*}$ - represents the decision / evaluation unit in comparison with the other decision units; The BCC model, introduced by Banker, Charnes and Cooper (1984), separates the technical efficiency of scale efficiency. Banker, Cooper, Seiford, Thrall and Zhu (2004) have shown that the effectiveness of the CCR can be considered as a product of a technical efficiency measure given by the BCC's efficiency score and a measure of scale efficiency.The BCC has also modified the original linear CCR formulation, adding a convex constraint for production, to estimate not only technical efficiency but also return to scale (Banker, Cooper, Seiford, Thrall and Zhu, 2004) . 
Since the CCR efficiency score is a product of technical efficiency and scale and the BCC measures pure technical efficiency, the ratio of yield scores $S_{k}=\frac{y_{k, C C R}}{y_{k, B C C}}$ produces a measure of the relative efficiency of the scale $D M U_{k}$, for $k=\overline{1, n}$.

\section{Applications of the DEA}

Emrouznejad, Parker \& Tavares (2008) offers a survey and analyzes DEA scientific literature by 2007; Liu, Lu, Lu \& Lin (2013), Liu, Lu \& Lu (2016), Thanassoulis, De Witte, Johnes, Johnes, Karagiannis \& Portela (2016), Emrouznejad \& Yang (2018) bring the latest updates to this field. The most influential journals are: European Journal Of Operational Research (EJOR), Journal Of The Operational Research Society (JORS), Journal Of Productivity Analysis (JPA), Management Science, Socio-Economic Planning Sciences ., Journal of Econometrics, Operations Research Letters, Operations Research, Computers \& Operations Research, Journal of the Operations Research Society of Japan, Omega: International Journal Of Management Science, International Journal of Systems Science, Applied Economics, Health Care Management Science, International Journal of Production Economics, Journal of Banking and Finance, and Energy Policy There are many applications and empirical studies who use efficiency and DEA methodology; we mention: banking application (Paradi, Zhu \& Edelstein - 2012, Chortareas, Girardone \& Ventouri - 2013, Apergis \& Polemis - 2016, Matousek \& Tzeremes 2016), education application (Mancebón, Calero, Choi \& Ximénez-De-Embún - 2012, Blackburn, Brennan \& Ruggiero - 2014, Johnes - 2015, Veiderpass \& McKelvey - 2016, Barra \& Zotti - 2016, Witte \& Lopez-Torres 2017), farm and agriculture application (Reimer \& Kang - 2010, Da Silva \& Gomes -2014, Skevas \& Serra 2016), health care and hospitals application (Fragkiadakis, Doumpos, Zopounidis \& Germain -2016, Vitezic, Segota \& Cankar - 2016, Fiallos, Patrick, Michalowski \& Farion -2017), transportation application (Chou, Lee, Chen. \& Tsa - 2016), sport (Cooper, Ruiz \& Sirvent - 2009, Halkos \& Tzeremes -2013, Lee \& Worthington 2013), public goods and services (Storto - 2016), energy application (Ignatius, Ghasemi, Zhang, Emrouznejad \& Hatami-Marbini -2016, Makridou, Andriosopoulos, Doumpos \& Zopounidis - 2016), company performance (Dobrea, Ciocoiu \& Dinu -2013, Peng, Huang \& Wu -2013, Ray -2015), public libraries (Liu \& Chuang - 2009, Shahwan \& Kaba -2013), tourist service (Cracolici, Cuffaro \& Nijkamp - 2008, Huang, Chiu, Ting \& Lin - 2012).

\section{Discussions}

The purpose is to determine with DEA a new perspective in benchmarking the efficiency of decision-making units in different sectors of activity.

In order to achieve this goal, several aspects will be taken into account:

- defining a DEA model that manages both controllable and uncontrollable variables;

- determination of efficiency scores for each DMU over the entire analyzed period;

- determining a method to correct data errors associated with DMUs;

- establishing a mechanism to accurately and effectively detect outdated values in the dataset;

- the correct selection and inclusion of the variables in the DEA model, as well as the reasoning of the choice.

\section{References}

Apergis, N. \& Polemis M.L. (2016). Competition and efficiency in the MENA banking region: a non-structural DEA approach. Applied Economics, 48(54): pp. 5276-5291 [CrossRef].

Banker, R. D., Charnes, A. \& Cooper, W. W. (1984). Some models for estimating technical and scale inefficiencies in data envelopment analysis, Management Science, 30, pp 1078-1092., [Google Scholar] [CrossRef].

Banker, R.D., Cooper, W.W., Seiford, L.M., Thrall, R.M. \& Zhu, J. (2004). Returns to Scale in Different DEA Models. European Journal of Operational Research, Vol. 154, pp 345-362. [CrossRef].

Barra, C. \& Zotti, R. (2016). Measuring Efficiency in Higher Education: An Empirical Study Using a Bootstrapped Data Envelopment Analysis. Int. Adv. Econ. Res. , 22, pp. 11-33. [Google Scholar] [CrossRef].

Blackburn, V., S. Brennan S. \& Ruggiero J. (2014). Measuring efficiency in australian Schools: A preliminary analysis. Socio-Economic Planning Sciences, 48(1): pp. 4-9 [CrossRef]. 
Charnes, A., Cooper, W.W. \& Rhodes, E. (1978). Measuring the Efficiency of Decision Making Units. European Journal of Operational Research, 2(6), pp 429-444. [CrossRef].

Chortareas, G.E., Girardone C. \& Ventouri A. (2013). Financial freedom and bank efficiency: Evidence from the European Union. Journal of Banking and Finance, 37(4): pp. 1223-1231 [CrossRef].

Chou, H.W., Lee, C.Y., Chen, H.K. \& Tsai, M.Y. (2016). Evaluating airlines with slack-based measures and meta-frontiers. Journal of Advanced Transportation. 50(6): pp. 1061-1089 [CrossRef].

Cooper, W.W., Ruiz, J.L. \& Sirvent, I. (2009). Selecting non-zero weights to evaluate effectiveness of basketball players with DEA. European Journal of Operational Research. 195(2): pp. 563-574 [CrossRef].

Cracolici, M.F., Cuffaro, M. \& Nijkamp, P. (2008). Sustainable tourist development in Italian holiday destinations. International Journal of Services, Technology and Management. 10(1): pp. 39-47[CrossRef].

Da Silva, E.S.G. \& Gomes E. G. (2014). Management of agricultural research centers in Brazil: A DEA application using a dynamic GMM approach. European Journal of Operational Research. 240(3): pp.819-824 [CrossRef].

Dobrea, R.C., Ciocoiu, C.N. \& Dinu, F.A. (2013). The efficiency of investment at regional level in Romania: An approach with data envelopment analysis. Economic Computation and Economic Cybernetics Studies and Research. 47(2).

Emrouznejad, A., Parker, B.R. \& Tavares, G. (2008). Evaluation of research in efficiency and productivity: A survey and analysis of the first 30 years of scholarly literature in DEA. Socio-Economic Planning Sciences. , 42, pp. 151-157. [Google Scholar] [CrossRef].

Emrouznejad, A. \& Yang, G (2018). A survey and analysis of the first 40 years of scholarly literature in DEA: 1978-2016. Socio-Economic Planning Sciences, Volume 61, pp. 4-8, [CrossRef].

Farrell, M. J. (1957). The measurement of productive efficiency. Journal of the Royal Statistical Society, Series A, 120 (III), pp 253-281, JSTOR, ww.jstor.org/stable/2343100.

Fiallos, J., Patrick, J., Michalowski, W. \& Farion, K. (2017). Using data envelopment analysis for assessing the performance of pediatric emergency department physicians. Health Care Management Science, pp. 129140 [CrossRef].

Fragkiadakis, G., Doumpos, M, Zopounidis, C. \& Germain, C. (2016). Operational and economic efficiency analysis of public hospitals in Greece. Annals of Operations Research, 247(2): pp. 787-806 [CrossRef].

Halkos, G.E. \& Tzeremes, N.G. (2013). A Two-Stage Double Bootstrap DEA: The Case of the Top 25 European Football Clubs' Efficiency Levels. Managerial and Decision Economics 34(2): pp. 108-115 [CrossRef].

Huang, C.W., Chiu, Y.H., Ting, C.T. \& Lin, C.H. (2012). Applying a hybrid DEA model to evaluate the influence of marketing activities to operational efficiency on Taiwans international tourist hotels. Journal of the Operational Research Society 63(4): pp. 549-560 [CrossRef].

Ignatius, J., Ghasemi, M., Zhang, F., Emrouznejad, A. \& Hatami-Marbini, A. (2016). A. Carbon Efficiency Evaluation: An Analytical Framework Using Fuzzy DEA. European Journal of Operational Research [CrossRef].

Johnes, J. (2015). Operational research in education. European Journal of Operational Research 243(3): pp.683696 [CrossRef].

Lee, B.L. \& Worthington, A.C. (2013). A note on the 'Linsanity' of measuring the relative efficiency of National Basketball association guards. Applied Economics, 45(29): pp. 4193-4202 [CrossRef].

Liu, J.S., Lu, L.Y.\& Lu, W.M. (2016). Research fronts in data envelopment analysis. Omega 58, pp. 33-45. [CrossRef].

Liu, J.S., Lu, L.Y., Lu, W.M.\& Lin, B.J. (2013). Data envelopment analysis 1978-2010: A citation-based literature survey. Omega 41, pp. 3-15. [Google Scholar] [CrossRef].

Liu, S.T. \& Chuang, M. (2009). Fuzzy efficiency measures in fuzzy DEA/AR with application to university libraries. Expert Systems with Applications 36(2 PART 1): pp. 1105-1113, [CrossRef].

Makridou, G., Andriosopoulos, K., Doumpos, M. \& Zopounidis, C. (2016). Measuring the efficiency of energyintensive industries across european countries. Energy Policy, 88: pp. 573-583[CrossRef].

Mancebón, M.J., Calero J., Choi A. \& Ximénez-De-Embún, D.P. (2012). The efficiency of public and publicly subsidized high schools in Spain: Evidence from PISA-2006. Journal of the Operational Research Society 63(11): pp. 1516-1533 [CrossRef].

Matousek, R. \& Tzeremes N.G. (2016). CEO compensation and bank efficiency: An application of conditional nonparametric frontiers. European Journal of Operational Research 251(1): pp. 264-273 [CrossRef]. 
Paradi, J.C., Zhu, H \& Edelstein B. (2012). Identifying managerial groups in a large Canadian bank branch network with a DEA approach. European Journal of Operational Research 219(1): pp. 178-187 [CrossRef].

Peng, K.H., Huang, J.H. \& Wu, W.H. (2013). Rasch model in data envelopment analysis: Application in the international tourist hotel industry. Journal of the Operational Research Society 64(6): pp. 938-944 [CrossRef].

Ray, S.C. (2015). Nonparametric measures of scale economies and capacity utilization: An application to U.S. manufacturing. European Journal of Operational Research 245(2): pp. 602-611[CrossRef].

Reimer, J.J. \& Kang, S.M. (2010). Estimation of trade and domestic distortions: An application to world agriculture. Journal of Productivity Analysis 34(3), pp. 257-265; http://www.jstor.org/stable/41770930.

Shahwan, T.M. \& Kaba, A. (2013). Efficiency analysis of GCC academic libraries: An application of data envelopment analysis. Performance Measurement and Metrics. 14(3): pp. 197-210 [CrossRef].

Skevas, T. \& Serra, T. (2016). The role of pest pressure in technical and environmental inefficiency analysis of Dutch arable farms: an event-specific data envelopment approach. Journal of Productivity Analysis 46(23): pp. 139-153[CrossRef].

Storto, C.I. (2016). The trade-off between cost efficiency and public service quality: A non-parametric frontier analysis of Italian major municipalities. Cities 51: pp. 52-63 [CrossRef].

Thanassoulis, E., De Witte, K., Johnes, J., Johnes, G., Karagiannis, G. \& Portela, C. (2016). Applications of Data Envelopment Analysis in Education, In Data envelopment analysis: a handbook of empirical studies and applications, Springer, pp. 367-438. [CrossRef].

Veiderpass, A., \& McKelvey M. (2016). Evaluating the performance of higher education institutions in Europe:a nonparametric efficiency analysis of 944 institutions. Applied Economics, 48(16): pp. 1504-1514 [CrossRef].

Vitezic, N., Segota, A.\& Cankar, A.A. (2016). Measuring the Efficiency of Public Health Services by DEA. International Public Administration Review vol. 14 , pp 27-48. [CrossRef].

Witte, K.D. \& Lopez-Torres, L. (2017). Efficiency in education: A review of literature and a way forward. Journal of the Operational Research Society, 68, pp. 339-363. [Google Scholar] [CrossRef]. 